\title{
STRATEGI PENINGKATAN MUTU PERGURUAN TINGGI AGAMA ISLAM BERBASIS BALANCED SCORECARD
}

\author{
Machasin, dkk. \\ IAIN Walisongo Semarang \\ e-mail:machasin@yahoo.com
}

\begin{abstract}
This study is a policy research, which use STAIN in Central Java as objects of research, while faculty, students, employees, officers and graduates of the unit being analyzed. The analysis technique used is exsploratif descriptive. To implement the balanced scorecard at STAIN would require accurately data and documents, it is to be aware of changes in key indicators that can be used as the basis of evidence the organization's activities. In this study, the perspective which used is the perspective of stakeholders, administrative and financial management, and the teaching and learning process, work ethos, culture and good governance. The results of the five perspective are refered to the differences of implementation, but for administrative and financial management perspective STAIN, in Central Java, faced the same thing that is the not optimal care units so that are still limited contribution to STAIN revenue.
\end{abstract}

\begin{abstract}
$* * *$
Kajian ini merupakan kajian kebijakan, yang menggunakan STAIN di Jawa Tengah sebagai obyek penelitian, dengan pejabat fakultas, mahasiswa, pegawai, dan lulusan yang menjadi obyek analisis. Teknik analisis yang digunakan adalah deskriptif eksploratif, dengan perspektif stakeholder, pejabat administratif dan keuangan, proses belajar mengajar, etos kerja, budaya, dan dan good governance. Hasil dari lima perspektif ini menunjukkan adanya perbedaan implementasi, sementara dari perspektif pengelola administrasi dan keuangan menghadapi masalah yang sama yaitu tidak optimalnya unit-unit perawatan sehingga masih kecil kontribusinya bagi perolehan STAIN.
\end{abstract}

Keywords: balanced scorecard, mutu PTAI, STAIN 


\section{A. Pendahuluan}

Arah strategi pengembangan perguruan Tinggi Agama Iskam (PTAI) adalah PTAI mampu menghasilkan lulusan yang Islami dan unggul dalam mengintegrasikan keilmuan dengan nilai keislaman. Oleh karen itu penyelenggaraan pendidikan tinggi yang dilaksananakan oleh lembaga Perguruan Tinggi Agama Islam Negeri (PTAIN) dan 539 Perguruan Tinggi Agama Islam Swasta (PTAIS) harus dilandasi dengan penyelenggaraan pendidikan yang selaras dengan prinsip prinsip profesionalisme dan prinsip good governance yang terintegrasi dalam pembinaan kepribadian dan pengembangan jaringan akademis yang didukung oleh ketersediaan tenaga pendidik yang berkualitas. Ketersediaan tenaga pendidik PTAI berdasarkan kualifikasi pendidikan dapat dijelaskan pada tabel 1 .

Tabel 1.

Jumlah Kualifikasi Pendidikan pada PTAI Tahun 2007/2008

\begin{tabular}{|l|l|l|l|l|l|l|l|l|}
\hline \multirow{2}{*}{ No. } & \multirow{2}{*}{$\begin{array}{c}\text { Jenis } \\
\text { PTAI }\end{array}$} & \multicolumn{3}{|c|}{ Status Ketenagaan } & \multicolumn{4}{c|}{ Kualifikasi Pendidikan } \\
\cline { 3 - 9 } & & Tetap & $\begin{array}{c}\text { Tidak } \\
\text { Tetap }\end{array}$ & Jumlah & S-1 & S-2 & S-3 & Jumlah \\
\hline 1. & UIN & 2.698 & 2.274 & 4.972 & 1.216 & 3.206 & 550 & 4.972 \\
\hline 2. & IAIN & 2.956 & 1.473 & 4.429 & 1.505 & 2.623 & 301 & 4.429 \\
\hline 3. & STAIN & 2.461 & 1.500 & 3.961 & 1.458 & 2.357 & 146 & 3.961 \\
\hline 4. & PTAIS & 9.539 & 12.868 & 22.407 & 10.803 & 9.960 & 1.644 & 22.407 \\
\hline Jumlahy & 17.654 & 18.115 & 35.769 & 14.982 & 18.146 & 2.641 & 35.769 \\
\hline \multicolumn{2}{|l|}{ Prosentase } & 49,36 & 50,64 & 100,00 & 41,89 & 50,73 & 7,38 & 100,00 \\
\hline
\end{tabular}

Sumber: Data Direktorat Pendidikan Tinggi Islam TA 2007-2008

Pada tabel 1 menunjukan bahwa kualifikasi tenaga pendidikan di PTAI 50,73 berpendidikan S2, 41,89\% berpendidikan S1 dan yang perpendidikan S3 hanya 7,38\%. Kondisi ini merupakan salah satu kelemahan pengembangan PTAI yang berimplikasi pada lemahnya mutu PTAI, sehingga kebijakan pengembangan PTAI difokuskan pada tahun 2010-2014 pengembangan PTAI yang mampu menghasilkan lulusan (intelektual Muslim) yang unggul dalam mengintegrasikan keilmuan dengan nilai keislaman, dilandasi penyelenggaraan pendidikan yang selaras dengan prinsip profesionalisme dan good governance yang terintegrasi dengan pembinaan kepribadian yang berdaya saing. 
Isu utama dalam peningkatan mutu PTAI adalah peningkatan kompetensi dan profesionalisme pendidik dan tenaga kependidikan untuk mencapai visi dan misi PTAI melalui meningkatkan kualitas pendidik dan tenaga kependidikan melalui standar kualifikasi pendidikan, peningkatan kompetensi serta profesionalisme. Untuk menuju tercapainya mutu pendidikan dan tata kelola PTAI yang bersih dan transparan, peneliti menawarkan konsep balanced scorecard yang bersifat teknis, taktis dan operasional dengan mengimplementasikan prinsisp-prinsip good governance sebagai bahan kebijakan strategi pengembangan PTAI di masa yang akan datang. Selama ini balanced scorecard sukses diterapkan pada perusahaan-perusahaan bisnis di Eropa dan Australia, oleh peneliti kembangkan sebagai suatu strategi peningkatan mutu pendidikan dan kelembagaan PTAI dengan harapan dapat terwujudnya penyelenggaran Pendidikan Tinggi Islam yang menjunjung tinggi nilai-nilai amanah, tafaqquh fi ' l-dinn, profesional, transparan, akuntabel dan berkualitas.

Dalam penelitian awal yang dilakukan ada beberapa persoalan yang muncul seputar penyelenggaraan PTAI di Jawa Tengah antara lain pada kualitas, potensi, sistem, etos kerja, dana, sarana, dan prasarana, atau persoalan yang berkaitan dengan perannya dalam membangun SDM yang merupakan indikator menentukan standar kualitas PTAI. Secara tidak langsung, kompetensi output dan outcome tidak saja akan membawa citra terhadap PTAI, tetapi secara luas juga terkait erat dengan citra PTAI dalam menjalankan salah satu kewajibannya, yakni menyelenggarakan pendidikan tinggi agama yang berkualitas.

Berdasarkan realita tersebut, maka diperlukan suatu rumusan kebijakan dalam pengembangan PTAI yang menitikberatkan pada peningkatan kualitas PTAI dengan pendekatan balanced scorecard. Balanced scorecard diciptakan untuk menetapkan tujuan dan sekaligus melakukan pengukuran kinerja PTAI, sehingga secara langsung sistem ini taktis dan operasional dalam upaya meningkatkan mutu PTAI yang berdaya saing. Selama ini kebijakan yang diterapkan dalam meningkatkan mutu PTAI tidak berorientasi pada hasil riset, sehingga kebijakan-kebijakan diterapkan kurang efektif. Oleh karena itu penelitian menawarkan konsep balanced scorecard dan menerapkan prinsipprinsip good governance, dengan harapan strategi ini dapat meningkatkan kualitas pendidik dan tenaga kependidikan serta tatakelola PTAI yang bersih, transparan dan akuntabel pada akhirnya dapat meningkatkan kepuasan stakeholders. 
Dengan mengembangkan model balanced scorcard dari Kaplan ${ }^{1}$ yang didasarkan pada 5 (lima) perspektif, anatara lain: pemangku kepentingan (stakeholders), manajemen administrasi dan keuangan (administration and finance), proses pendidikan dan pengembangan (teaching and learning), etos kerja dan budaya (ethos and culture) dan good governance yang terintegrasi dalam suatu model strategi peningkatan mutu PTAI. Model balanced scorecard ini sangat tepat di implementasikan pada lembaga PTAI dalam usaha turut serta dalam mencerdaskan masyarakat serta memberi beberapa kontribusi dalam mewujudkan bangsa yang berdaya saing. Adapun tujuan penelitian adalah: (1) untuk mengetahui implementasi balanced scorecard pada PTAI di Jawa Tengah dan (2) strategi yang digunakan dalam rangka meningkatkan mutu pendidikan di PTAI berdasarkan pendekatan balanced scorecard.

\section{B. Konsep Balanced Scorecard}

Balanced scorecard merupakan sistem manajemen strategis yang menerjemahkan visi dan strategi suatu organisasi ke dalam tujuan dan ukuran operasional. ${ }^{2}$ Tujuan dan ukuran operasional tersebut kemudian dinyatakan dalam empat perspektif yaitu perspektif finansial, pelanggan (customers), proses bisnis internal (internal business process), serta pembelajaran dan pertumbuhan (learning and growth). ${ }^{3}$ Perspektif finansial menggambarkan keberhasilan finansial yang dicapai oleh organisasi atas aktivitas yang dilakukan dalam 3 perspektif lainnya. Perspektif pelanggan menggambarkan pelanggan dan segmen pasar dimana organisasi berkompetisi. Perspektif proses bisnis internal mengidentifikasikan proses-proses yang penting untuk melayani pelanggan dan pemilik organisasi. Perspektif pembelajaran dan pertumbuhan menggambarkan kemampuan organisasi untuk menciptakan pertumbuhan jangka panjang. Balanced scorecard sebagai suatu kerangka kerja atau sistem manajemen yang mengintegrasikan visi, strategi dan keempat perspektif secara seimbang. Pendekatan perspektif keuangan dalam balanced scorecard merupakan hal yang sangat penting, hal ini disebabkan ukuran

\footnotetext{
1 Kaplan, Robert S dan David P. Norton, Balanced Scorecard: Translating Strategy Into Action, (Boston: Havard Business School Press, 1996).

2 Mowen, J.C, Customer Behavior, (New Jersey: Prentice Hall Inc., 1995).

${ }^{3}$ Kaplan, RobertS dan David P. Norton, Balanced Scorecard: Translating Strategy Into Action.
} 
keuangan merupakan suatu konsekwensi dari suatu keputusan ekonomi yang diambil dari suatu tindakan ekonomi. Ukuran keuangan ini menunjukkan adanya perencanaan, implementasi.

Pada masa lalu seringkali perusahaan mengkonsentrasikan diri pada kemampuan internal dan kurang memperhatikan kebutuhan konsumen. Sekarang strategi perusahaan telah bergeser fokusnya dari internal ke eksternal. Jika suatu unit bisnis inin mencapai kinerja keuangan yang superior dalam jangka panjang, mereka harus menciptakan dan menyajikan suatu produk atau jasa yang bernilai dari biaya perolehannya. Dan suatu produk akan semakin bernilai apabila kinerjanya semakin mendekati atau bahkan melebihi dari apa yang diharapkan dan persepsikan konsumen.

Kaplan $^{4}$ menjelaskan untuk memasarkan produknya perusahaan terlebih dahulu harus menentukan segmen calon pelanggan mana yang harus dimasuki oleh perusahaan, dengan demikian akan lebih jelas dan lebih terfokus tolok ukurnya. Dewasa ini fokus strategi perusahaan lebih diarahkan pada pelanggan (customer drive strategy), dengan kata lain apa yang dibutuhkan pelanggan harus dipenuhi oleh perusahaan. Kinerja produk yang dihasilkan perusahaan minimal harus sama dengan apa yang dipersepsikan oleh pelanggan. Tolok ukur kinerja pelanggan dibagi menjadi dua kelompok (Budi W. Soejtipto, 1997): Pertama, kelompok inti yang terdiri dari: (1) Pangsa pasar: mengukur seberapa besar porsi segmen pasar tertentu yang dikuasai oleh perusahaan; (2) Tingkat perolehan para pelanggan baru: mengukur seberapa banyak perusahaan berhasil menarik pelanggan-pelanggan baru; (3) Kemampuan mempertahankan para pelanggan lama: mengukur seberapa banyak perusahaan berhasil mempertahankan pelanggan-pelanggan lama; (4) Tingkat kepuasan pelanggan: mengukur seberapa jauh pelanggan merasa puas terhadap layanan perusahaan dan (5) Tingkat profitabilitas pelanggan: mengukur seberapa besar keuntungan yang berhasil diraih oleh perusahaan dari penjualan produk kepada para pelanggan. Sedangkan kelompok kedua, kelompok penunjang yang terdiri dari: (1) Atribut-atribut produk; (2) Hubungan dengan pelanggan, dan (3) Citra dan reputasi perusahaan beserta produk-produknya dimata para pelanggannya dan masyarakat konsumen.

${ }^{4}$ Ibid. 
Penilaian kinerja yang ketiga dengan prespektif bisnis internal. Untuk bisa menggunakan tolok ukur kinerja ini, maka perusahaan harus mengidentifikasi proses bisnis internal yang terjadi pada perusahaan. Secara umum proses tersebut terdiri dari inovasi, operasi dan layanan purna jual. ${ }^{5}$ Perpektif proses bisnis internal mengidentifikasikan proses-proses yang pentig bagi organisasi untuk melayani pelanggan (persepektif pelanggan) dan pemilik organisasi (perpektif finansial). Komponen utama dalam proses bisnis internal adalah: (1) proses inovasi, yang diukur dengan banyaknya produk baru yang dihasilkan organisasi, waktu penyerahan produk ke pasar, dan lainnya; (2) proses operasional, yang diukur dengan peningkatan kualitas produk, waktu proses produksi yang lebih pendek, dan lainnya; (3) proses pelayanan, yang diukur dengan pelayanan purna jual, waktu yang dibutuhkan untuk memberikan pelayanan kepada pelanggan, penanganan keluhan pelanggan dan lainnya.

Perspektif keempat dalam balanced scorecard mengembangkan pengukuran dan tujuan untuk mendorong organisasi agar berjalan dan tumbuh. Tujuan dari perspektif pembelajaran dan pertumbuhan adalah menyediakan infrastruktur untuk mendukung pencapaian tiga perspektif sebelumnya. Perspektif keuangan, pelanggan dan sasaran dari proses bisnis internal dapat mengungkapkan kesenjangan antara kemampuan yang ada dari orang, sistem dan prosedur dengan apa yang dibutuhkan untuk mencapai suatu kinerja yang handal. Untuk memperkecil kesenjangan tersebut perusahaan harus melakukan investasi dalam bentuk re skilling employees.

Adapun faktor-faktor yang harus diperhatikan adalah: ${ }^{6}$ (1) Kapabilitas karyawan. Hal yang perlu ditinjau adalah kepuasan karyawan dan produktivitas kerja karyawan. (2) Kemampuan Sistem Informasi. Perusahaan perlu memiliki prosedur informasi yang mudah dipahami dan mudah dijalankan. Tolok ukur yang sering digunakan adalah bahwa informasi yang dibutuhkan mudah didapatkan, tepat dan tidak memerlukan waktu lama untuk mendapat informasi tersebut, dan (3) motivasi, pemberdayaan dan keselarasan.

Setiap tujuan dan ukuran dari setiap perspektif merupakan suatu hubungan sebab akibat, artinya jika tujuan dari perspektif pelanggan, proses bisnis internal, dan pembelajaran dan pertumbuhan tercapai, maka pada

\footnotetext{
${ }^{5}$ Ibid.

${ }^{6}$ Ibid., h. 126.
} 
akhirnya adalah peningkatan kinerja finansial organisasi. Hubungan sebab akibat merupakan komponen penting dalam performance measurement model karena hubungan sebab akibat dapat membantu memprediksi tujuan finansial yang akan tercapai, dan dapat menciptakan proses pembelajaran, motivasi dan komunikasi yang efektif.

\section{Balanced Scorecard pada Lembaga Pendidikan}

Program Kualitas Nasional Baldrige memulai proses mengubah kriteria bisnis untuk digunakan didalam sektor pendidikan. Konsep balanced scorecard telah diadopsi secara luas dan digunakan didalam sektor bisnis, sedangkan untuk sektor pendidikan konsep balanced scsorecard tidak digunakan secara luas, sebagaimana diindikasikan oleh kurangnya penelitian yang diterbitkan tentang topik ini. Sebuah kajian literatur yang menyeluruh menghasilkan beberapa terbitan yang signifikan. Cullen, Joyce, Hassal dan Broadbent (2003) mengusulkan bahwa pendekatan balanced scorecard digunakan di dalam lembaga-lembaga pendidikan untuk menguatkan pentingnya mengelola dan bukannya sekedar memantau kinerja. Sutherland (2000) melaporkan bahwa Jurusan Pendidikan Rossier di Universitas California Selatan mengadopsi pendekatan balanced scorecard untuk menaksir program akademik dan proses perencanaannya. Chang dan Chow (1999) melaporkan bahwa respon-respon didalam sebuah survei terhadap 69 kepala departemen akunting secara umum mendukung kebisaan diterapkan dan manfaatmanfaat dari balanced scorecard tersebut untuk program-program akunting.

Pentingnya pengukuran menyebarluaskan Kriteria Baldrige untuk Keunggulan Kinerja berdasarkan balanced scorecard pada lembaga pendidikan. Faktor-faktor ini meliputi dasar-dasar filosofis dari keunggulan kinerja balanced scorecard dan adalah sebagai berikut (Program Kualitas Nasional Baldrige, 2003b): (1) Kepemimpinan bervisi; (2) Pendidikan berpusat pada pembelajaran; (3) Pembelajaran organisasi dan pribadi; (4) Menghargai guru/dosen, staf dan para mitra; (5) Keaktifan; (6) Fokus pada masa depan; (7) Mengelola untuk inovasi; (8) Manajemen berdasarkan fakta; (9) Tanggung jawab sosial; (10) Fokus pada hasil-hasil dan menciptakan nilai dan (11) Perspektif sistem.

Inti dan konsep balanced scorecard pada lembaga pendidikan yang diwujudkan dalam enam kategori pertama menghasilkan: pertama, mahasiswa 
hasil belajar harus-harus berdasarkan ragam metode penilaian dan merefleksikan keseluruhan organisasi, misi, tujuan dan peningkatan diambil bersama mewakili suatu holistik penilaian belajar siswa (pelanggan perspektif). Kedua, mahasiswa dan stakeholder, fokus hasil pengukuran kepuasan, harus melibatkan pendidikan khusus program dan layanan pendidikan yang mengarah pada pengembangan hasil belajar siswa serta stakeholder untuk masa depan (perspektif pelanggan). Ketiga anggaran, keuangan, dan pasar, jika hasil mencakup instruksional dan pengeluaran administrasi umum melalui mahasiswa, biaya kuliah dan biaya tingkat, biaya per akademik kredit, sumber daya diarahkan kependidikan dari daerah lain, dan beasiswa pertumbuhan (perspektif keuangan). Keempat, fakultas dan staf, hasilnya harustermasuk inovasi dan tarif saran, program pendidikan atau magang di tempat kerja-kinerja perbaikan, pelatihan dan kerja sama tim, pengetahuan dan keterampilan berbagi di banyak bekerja di fungsi, unit, dan lokasi, kesejahteraan karyawan, kepuasan, ketidakpuasan dan (belajar dan perspektif pertumbuhan). Kelima, efektivitas organisasi hasil, termasuk kunci internal yang operasional-ukuran kinerja, harus-meliputi: kapasitas untuk meningkatkan kinerja pelajar dan mahasiswa pembangunan, iklim pendidikan, indikator tanggap untuksiswa atau kebutuhan stakeholder, pemasok dan mitra kinerja, tindakan kunci atau indikator pencapaian strategi organisasi, dan rencana aksi (perspektif proses bisnis internal). Keenam, tata kelola dan tanggung jawab sosial, jika hasil mencakup internal dan akuntabilitas eksternal fiskal, tindakan atau indikator perilaku etis dan kepercayaan pemangku kepentingan dalam pemerintahan organisasi, peraturan dan hukum kepatuhan, dan organisasi kewarganegaraan (tata kelola dan tanggung jawab sosial perspektif).

\section{Implemenetasi Balanced Scorecard pada Lembaga Pendidikan}

Setelah membangun balanced scorecard maka langkah selanjutnya adalah mengimplementasikan apa yang telah dibangun atau disusun. Langkah pertama dalam mengimplementasikan balanced scorecard adalah team yang telah disusun melakukan identifikasi data yang diperlukan untuk mengimplementasikan balanced scorecard. Selanjutnya menentukan teknologi informasi yang digunakan untuk memudahkan proses mengkomunikasikan balanced scorecard. Implementasi dari balance scorecard tidak bisa langsung 
dilakukan pada setiap unit organisasi secara bersamaan, tetapi harus dilakukan secara bertahap. Langkah kedua adalah membangun scorecard secara menyeluruh. Pada awalnya balanced scorecard dibuat pada tingkat organisasi, yang kemudian diterjemahkan ke dalam balanced scorecard unitunit dalam organisasi, diterjemahkan lagi ke dalam balanced scorecard departemen, dan yang terakhir adalah balanced scorecard tim atau individu. Pada tahapan ini tim yang terbentuk mengkomunikasikan inisiatif strategis dan ukuran yang dibutuhkan untuk setiap perspektif kepada manager dari masing-masing unit organisasi.

Dalam penelitian Nomura Research Institute (NRI) Papers No. 45, 1 April 2002 dikemukakan bahwa Jepang sudah beberapa tahun lalu mengintroduksikan pola kerja balance scorecard terhadap lebih dari 20 perusahaan (Morisawa, 2002: 3). Dari hasil penelitiannya, NRI dapat memberi kesimpulan bahwa berdasarkan pengalaman-pengalaman perusahaan yang menerapkan pengukuran kinerja dengan balanced scorecard tersebut merasakan bahwa balanced scorecard memang memiliki keunggulan yang dirangkum menjadi lima point sebagai berikut: (1) Balanced scorecard dapat digunakan untuk melakukan perbaikan keseimbangan di antara sasaran-sasaran jangka pendek, jangka menengah, dan jangka panjang; (2) Dapat menciptakan pemahaman strategi perubahan dengan menyusun atau menetapkan indikatorindikator non-finansial kuantitatif disamping indikator-indikator finansial; (3) Mengurangi keragu-raguan atau kekaburan dengan tetap menjaga indikator-indikator non finansial kuantitatif; (4) Mempromosikan proses pembelajaran organisasi melalui suatu pengulangan siklus hipotesis verifikasi, dan 5) Memperbaiki platform strategi komunikasi secara umum dalam organisasi yang mencerminkan keterkaitan antara pimpinan dan bawahan.

Meskipun konsep balanced scorecard telah telah banyak diadopsi dan digunakan dalam sektor bisnis, sektor pendidikan ternyata belum memeluk balanced scorecard konsep luas, seperti ditunjukkan oleh kelangkaan penelitian diterbitkan pada ini topik. Sebuah tinjauan literatur menyeluruh signifikan menghasilkan beberapa publikasi misalnya, Cullen, Joyce, Hassall, dan Broadbent (2003) mengusulkan bahwa balanced scorecard digunakan dalam pendidikan institusi untuk penguatan pentingnya mengelola bukan hanya pemantauan kinerja. Sutherland (2000) melaporkan bahwa Rossier Sekolah Pendidikan di University of Southern California mengadopsi seimbang pendekatan scorecard untuk menilai akademis program dan proses 
perencanaan. Chang dan Chow (1999) melaporkan bahwa respon dalam survei dari 69 akuntansi kepala departemen pada umumnya mendukung dari balanced scorecard yang penerapan dan manfaat akuntansi program.

Kajian balanced scorecard dikembangkan dalam program kualitas Baldrige National dengan tujuan membantu bisnis-bisnis Amerika memperbaiki daya saing mereka didalam pasar global. Bisnis-bisnis bisa memperbaiki daya saing mereka dengan mengidentifikasi organisasi-organisasi model peran, mengenali mereka, dan menyebarluaskan praktek-praktek terbaik mereka di seluruh Amerika Serikat. Program Baldrige diakui secara luas sebagai sebuah faktor yang sangat signifikan didalam memperkuat daya saing AS di pasar global (Program Kualitas Nasional, Baldrige, 2003a)

Program Baldrige adalah kriteria untuk keunggulan kinerja, kriteria ini mendefinisikan sebuah model manajemen paling canggih yang memadukan tujuan wilayah berikut ke dalam sebuah sistem yang kompehensif: kepemimpinan; perencanaan strategis; fokus konsumen dan pasar; pengukuran, analisis dan manajemen pengetahuan; fokus sumber daya manusia; manajemen proses; dan hasil-hasil bisnis.

Kriteria tersebut memberi penekanan yang kuat pada pengembangan sebuah sistem yang komprehensif yang disesuaikan dengan tujuan-tujuan strategis perusahaan. Sistem pengukuran tersebut menghasilkan hasil-hasil didalam wilayah-wilayah berikut (Program Kualitas Nasional Baldrige, 2003a): (1) hasil-hasil yang berfokus konsumen; (2) hasil-hasil produk dan layanan; (3) hasil-hasil keuangan dan pasar; (4) hasil-hasil sumber daya manusia; (5) hasil-hasil efektivitas organisasi termasuk ukuran-ukuran kinerja operasi-operasi internal kunci, dan (6) hasil-hasil tata kelola dan tanggung jawab sosial.

Implementasi balanced scorecard juga dilakukan pada University of Wisconsin-Stout dengan menggunakan indikator dan ukuran sebagai berikut: (1) Dimensi student-learning results/siswa-hasil belajar; (2) Dimensi student and stakeholder focused results/mahasiswa dan stakeholder terfokus hasil; (3) Dimensi budgetary and financial results; (4) Dimensi faculty and staff results, dan (5) Dimensi organizational effectiveness results.

Dengan berbagai kombinasi, eksperimen, pengalaman, penerapan serta pengembangan, balanced scorecard umumnya diimplementasikan pada perusahaan bisnis, oleh peneliti dikembangkan menjadi suatu model penilaian 
peningkatan mutu PTAI yang berbasis kinerja dan telah disesuaikan dengan tata kelola PTAI khususnya STAIN di Jawa tengah. Tujuan dari implementasi balanced scorecard menghasilkan model peningkatan mutu dan tata keloa PTAI yang profesional, transparan dan akuntabel berdasarkan 5 (lima) perspektif antara lain: perspektf pemangku kepentingan (stakeholders), manajemen administrasi dan keuangan (administration and finance), proses pendidikan dan pengembangan (teaching and learning), etos kerja dan budaya (ethos and culture) dan good governance. Perspektif-perspektif dalam balanced scorecard menunjukkan capaian yang ingin dihasilkan serta menggambarkan strategi pertambahan nilai (value added) organisasi PTAI secara komprehensip dan holistik. Perpektif dan indikator balanced scorecard yang dikembangkan oleh peneliti dapat dijelaskan pada kerangka pemikiran gambar 1. Dengan harapan penelitian ini, akan dihasilkan suatu rumusan kebijakan dalam upaya peningkatan mutu PTAI, hal ini sesuai dengan dengan program PTAI sebagai center of excellence dengan mengimplementasikan balanced scorecrad berdasarkan prinsip-prinsip tatakola kelembagaan yang bersih (good governance) yang ditinjau dari berbagai perpsektif sehingga dapat menghasilkan kebijakan ini bersifat komprehensif dan holistik yang dibutuhkan dalam peningkatan mutu PTAI.

\section{E. Kerangka Pemikiran}

Visi dan strategi diterjemahkan ke dalam 5 perspektif yang kemudian oleh masing-masing perspektif visi dan strategi tersebut dinyatakan dalam bentuk tujuan yang ingin dicapai oleh PTAI, ukuran (measures) dari tujuan, target yang diharapkan dimasa yang akan datang serta inisiatif-inisiatif atau program yang harus dilaksanakan untuk memenuhi tujuan-tujuan strategis PTAI. Proses menerjemahkan visi dan strategi PTAI yang dikembangkan berdasarkan 5 (lima) perspektif antara lain: perspektf pemangku kepentingan (stakeholders), manajemen administrasi dan keuangan (administration and finance), proses pendidikan dan pengembangan (teaching and learning), etos kerja dan budaya (ethos and culture) dan good governance.

Dalam perspektif pemangku kepentingan (stakeholders), PTAI mengidentifikasikan pelanggan dan segmen pasar dimana organisasi akan bersaing. Tujuan yang bisa ditetapkan dalam perspektif ini adalah pemuasan kebutuhan pelanggan/stakeholders. Ukuran-ukuran yang digunakan dalam perspektif ini antara lain: peningkatan jumlah mahasiswa yang diterima, 
peningkatan jumlah lulusan, peningkatan lulusan yang dapat bekerja/ berusaha, peningkatan instansi yang menggunakan lulusan, peningkatan hasil penelitian murni oleh dosen, peningkatan hasil penelitian terapan oleh dosen, peningkatan hasil penelitian oleh mahasiswa, peningkatan publikasian hasil penelitian, peningkatan pembinaan pesantren, madrasah dan desa binaan, penyelesaian kegiatan program penanggulangan masalah sosial, rekruitmen calon mahasiswa yang berprestasi, pemberian beasiswa kepada mahasiswa kurang mampu dan peningkatan kualitas kerjasama dengan pihak ketiga.

Dalam perspektif ini merumuskan tujuan manajemen administrasi dan keuangan yang ingin dicapai organisasi dimasa yang akan datang. Selanjutnya tujuan manajemen administrasi dan keuangan tersebut dijadikan dasar bagi ketiga perspektif lainnya dalam menetapkan tujuan dan ukurannya. Tujuan manajemen administrasi dan keuangan PTAI berhubungan dengan peningkatan kualitas sistem informasi keuangan, nilai tingkat kinerja pelayanan, economic value-added dari unit usaha, peningkatan kualitas SDM yang mengikuti pelatihan bidang pemeriksaan, nilai kesehatan finansial, peningkatan unit-unit usaha dalam memberikan kontribusi pendanaan terhadap pengembangan mutu akademik, peningkatan pembiayaan organisasi publik dan organisasi non profit luar negeri terhadap total anggaran PTAI, pembiayaan organisasi publik dan organisasi non profit luar negeri terhadap, Pembiayaan organisasi publik dan organisasi non profit luar negeri terhadap, Pembiayaan pemerintah terhadap total anggaran PTAI, pembiayaan dari mitra dalam negeri terhadap total anggaran PTAI, pembiayaan dari mahasiswa terhadap total anggaran PTAI, unit cost pendidikan per mahasiswa per tahun dan peningkatan pemeliharaan sarana teknologi informasi dalam rangka mengefektifkan sistem informasi akademik.

Perpektif proses pendidikan dan pengembangan (teaching and learning) mengidentifikasikan proses-proses yang pentig bagi organisasi untuk melayani pemangku kepentingan (persepektif stakeholders) dan pemilik organisasi (perpektif manajemen administrasi dan keuangan). Komponen utama dalam proses pendidikan dan pengembangan (teaching and learning) adalah: relevansi kurikulum sesuai dengan perkembangan masyarakat, peningkatan penambahan koleksi yang tersedia di perpustakaan, prosentase dosen yang mengajar sesuai dengan keahlian atau latar belakang pendidikannya, komposisi dosen berpendidikan S3 per jumlah seluruh dosen, rasio komposisi dosen per mahasiswa, rasio jumlah pegawai per mahasiswa, jumlah dosen yang mengikuti studi lanjut per jumlah dosen, prosentase pegawai/staf struk- 
tural yang dapat menduduki jabatan dan/melaksanakan tugas sesuai dengan keahliannya, prosentase pegawai yang mendapatkan predikat baik, prosentase dosen yang mendapatkan predikat baik, prosentase pejabat struktural yang berkinerja baik, prosentase pegawai yang berkinerja baik dan ratarata indeks kepuasan pegawai atas pelayanan.

Perspektif ini menggambarkan kemampuan organisasi untuk menciptakan etos kerja dan budaya kerja. Perspektif ini bertujuan meningkatkan kemampuan karyawan, meningkatkan kapabilitas sistem informasi, dan peningkatan keselarasan dan motivasi karyawan. Ukuran yang bisa digunakan antara lain rata-rata indeks kepuasan mahasiswa terhadap pelayanan akademik, rata-rata indeks kepuasan mahasiswa terhadap pelayanan non akademik, rata-rata indeks kepuasan alumni dan/atau masyarakat terhadap pelayanan, prosentase daya serap kurikulum yang sesuai dengan perkembangan kebutuhan, prosentase sarjana yang lulus dengan rata-rata masa pendidikan $\leq 5$ tahun, prosentase sarjana yang lulus dengan IPK $\geq 3,00$, prosentase fakultas yang dapat menerapkan metode belajar sesuai dengan manual penjaminan mutu pendidikan, peningkatan pengetahuan pegawai terhadap penggunaan dan akses teknologi dan peningkatan ketersediaan dan penggunaan sarana teknologi dan informasi bagi pegawai.

Konsep good governance ini merupakan salah satu konsep bagaimana tata kelola lembaga yang baik. Good governance pada perguruan tinggi diperlukan untuk mendorong terciptanya efisiensi, transparansi dan konsisten dengan peraturan perundang-undangan. Ukuran yang bisa digunakan perspektif good governance berdasarkan prinsip akuntabilitas (accountability), transparansi (transparancy), efisiensi, aturan hukum (rule of law) serta jaminan fairness, a level playing field (perlakuan yang adil/perlakuan kesetaraan). Prinsip-prinsip ini diperlukan di perguruan tinggi untuk mencapai kinerja yang berkesinambungan dengan tetap memperhatikan pemangku kepentingan.

Perguruan tinggi harus ditumbuhkan kesadaran bahwa tuntutan terhadap penerapan good governance tidak hanya merupakan kewajiban, tetapi lebih menjadi kebutuhan. Seiring dengan situasi persaingan yang makin ketat, perguruan tinggi harus terus berupaya mewujudkan tata kelola perguruan tinggi yang baik sebagai suatu sistem yang melekat dengan dinamika perguruan tinggi. Penerapan nilai-nilai good governance di perguruan tinggi dapat diinternalisasikan menjadi budaya perguruan tinggi, sehingga menjadi sebuah sistem yang memperkuat competitive advantage. Tujuan dari kebijak- 
an good governance di perguruan tinggi adalah agar pihak-pihak yang berperan dalam menjalankan pengelolaan perguruan tinggi memahami dan menjalankan fungsi dan peran sesuai wewenang dan tanggung jawab. Oleh karena itu kerangka pemikiran penelitian ini dapat dijelaskan pada gambar 1 .

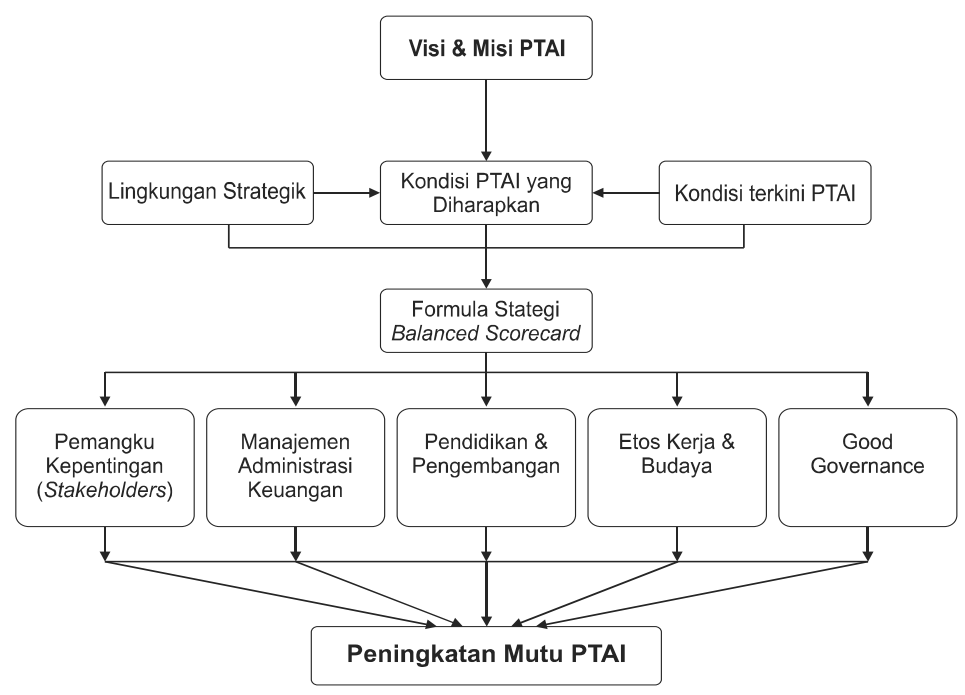

Gambar 1.

Kerangka Berpikir

1. Implementasi balanced scorecard dalam perspektif pemangku kepentingan (stakeholders) dapat dijelaskan pada tabel 2.

Tabel 2.

Balanced Scorecard dalam Perspektif Pemangku Kepentingan (Stakeholders) pada STAIN di Jawa Tengah

\begin{tabular}{|l|l|l|l|}
\hline \multirow{2}{*}{$\begin{array}{c}\text { Perspektif Pemangku Kepentingan } \\
\text { (Stakeholders) }\end{array}$} & \multicolumn{3}{c|}{ STAIN } \\
\cline { 2 - 4 } & Kudus & Pekalongan & Purwokerto \\
\hline Jumlah mahasiswa yang diterima & baik & baik & baik \\
\hline Jumlah mahasiswa & baik & baik & baik \\
\hline $\begin{array}{l}\text { Lulusan yang dapat bekerja/ } \\
\text { berusaha }\end{array}$ & kurang baik & baik & $\begin{array}{l}\text { tidak ada } \\
\text { kesimpulan }\end{array}$ \\
\hline
\end{tabular}




\begin{tabular}{|l|l|l|l|}
\hline $\begin{array}{l}\text { Instansi yang menggunakan } \\
\text { lulusan }\end{array}$ & $\begin{array}{l}\text { tidak ada } \\
\text { kesimpulan }\end{array}$ & baik & $\begin{array}{l}\text { tidak ada } \\
\text { kesimpulan }\end{array}$ \\
\hline Hasil penelitian murni oleh dosen & baik & kurang baik & kurang baik \\
\hline $\begin{array}{l}\text { Hasil penelitian terapan oleh } \\
\text { dosen }\end{array}$ & baik & kurang baik & kurang baik \\
\hline Hasil penelitian oleh mahasiswa & baik & baik & cukup baik \\
\hline $\begin{array}{l}\text { Publikasian hasil penelitian } \\
\text { Pembinaan pesantren, madrasah } \\
\text { dan desa binaan }\end{array}$ & cukup baik & $\begin{array}{l}\text { tidak ada } \\
\text { kesimpulan }\end{array}$ & kurang baik \\
\hline $\begin{array}{l}\text { Penyelesaian kegiatan program } \\
\text { penanggulangan masalah sosial. }\end{array}$ & cukup baik & kurang baik & cukup baik \\
\hline $\begin{array}{l}\text { Rekruitmen calon mahasiswa yang } \\
\text { berprestasi }\end{array}$ & $\begin{array}{l}\text { tidak ada } \\
\text { kesimpulan }\end{array}$ & cukup baik & cukup baik \\
\hline $\begin{array}{l}\text { Pemberian beasiswa kepada } \\
\text { mahasiswa kurang mampu }\end{array}$ & cukup baik & kurang baik & kurang baik \\
\hline $\begin{array}{l}\text { Kerjasama dengan pihak ketiga } \\
\text { tidak baik }\end{array}$ & baik & $\begin{array}{l}\text { tidak ada } \\
\text { kesimpulan }\end{array}$ \\
\hline
\end{tabular}

Sumber: Data penelitian diolah.

Pada tabel 2 menunjukkan terjadi perbedaan implementasi balanced scorecard dalam perspektif pemangku kepentingan (stakeholders) pada STAIN di Jawa Tengah dalam upaya meningkatkan mutu pendidikan, oleh karena itu ada beberapa kebijakan yang perlu mendapat perhatian dari STAIN dalam meningkatkan kinerjanya antara lain:

\begin{tabular}{|c|c|c|}
\hline No. & STAIN & Kebijakan \\
\hline 1 & Kudus & $\begin{array}{l}\text { 1. Meningkatkan rekuitmen mahasiswa baru yang } \\
\text { memiliki prestasi. } \\
\text { 2. Meningkatkan kerjasama dengan instansi/ lembaga } \\
\text { pengguna lulusan. } \\
\text { 3. Meningkatkan lulusan yang dapat bekerja atau } \\
\text { berusaha. }\end{array}$ \\
\hline 2 & Pekalongan & $\begin{array}{l}\text { 1. Meningkatkan jumlah penelitian dosen (terapan dan } \\
\text { ilmu murni) dalam ikut serta dalam memecahkan } \\
\text { permasalahan sosial masyarakat. } \\
\text { 2. Meningkatkan jumlah Publikasian hasil penelitian. } \\
\text { 3. Meningkatkan pemberian bea siswa bagi mahasiswa } \\
\text { miskin dan berprestasi. }\end{array}$ \\
\hline
\end{tabular}




\begin{tabular}{|c|c|c|c|}
\hline & & & $\begin{array}{l}\text { Meningkatkan Penyelesaian kegiatan program pe- } \\
\text { nanggulangan masalah sosial melalui desa, madrasah } \\
\text { dan pesantren binaan. }\end{array}$ \\
\hline 3 & Purwokerto & $\begin{array}{l}4 . \\
5 .\end{array}$ & $\begin{array}{l}\text { Peningkatkan kerjasama dengan instansi/lembaga } \\
\text { pengguna lulusan. } \\
\text { Meningkatkan jumlah lulusan yang dapat bekerja atau } \\
\text { berusaha. } \\
\text { Meningkatkan penelitian dosen (terapan dan ilmu } \\
\text { murni) dalam ikut serta dalam memecahkan per- } \\
\text { masalahan sosial masyarakat. } \\
\text { Meningkatkan Publikasian hasil penelitian. } \\
\text { Meningkatkan pemberian bea siswa bagi mahasiswa } \\
\text { miskin dan berprestasi. }\end{array}$ \\
\hline
\end{tabular}

2. Implementasi balanced scorecard dalam perspektif manajemen administrasi dan keuangan (administration and finance) dapat dijelaskan pada tabel 3.

Tabel 3.

Balanced Scorecard dalam Perspektif

Manajemen Administrasi dan Keuangan pada STAIN di Jawa Tengah

\begin{tabular}{|c|c|c|c|}
\hline \multirow{2}{*}{$\begin{array}{l}\text { Perspektif Manajemen } \\
\text { Administrasi dan Keuangan } \\
\text { (Administration and Finance) }\end{array}$} & \multicolumn{3}{|c|}{ STAIN } \\
\hline & Kudus & Pekalongan & Purwokerto \\
\hline $\begin{array}{l}\text { Jumlah anggaran untuk kualitas } \\
\text { sistem informasi keuangan } \\
\text { (dalam jutaan rupiah) }\end{array}$ & cukup baik & cukup baik & cukup baik \\
\hline Nilai tingkat kinerja pelayanan & cukup baik & cukup baik & cukup baik \\
\hline $\begin{array}{l}\text { Economic value-added dari Unit } \\
\text { Usaha }\end{array}$ & $\begin{array}{l}\text { tidak dapat } \\
\text { disimpulkan }\end{array}$ & $\begin{array}{l}\text { tidak dapat } \\
\text { disimpulkan }\end{array}$ & $\begin{array}{l}\text { tidak dapat } \\
\text { disimpulkan }\end{array}$ \\
\hline $\begin{array}{l}\text { Kualitas SDM yang mengikuti pe- } \\
\text { latihan bidang pemeriksaan } \\
\text { laporan keuangan }\end{array}$ & $\begin{array}{l}\text { tidak dapat } \\
\text { disimpulkan }\end{array}$ & $\begin{array}{l}\text { tidak dapat } \\
\text { disimpulkan }\end{array}$ & $\begin{array}{l}\text { tidak dapat } \\
\text { disimpulkan }\end{array}$ \\
\hline Nilai kesehatan finansial & $\begin{array}{l}\text { tidak dapat } \\
\text { disimpulkan }\end{array}$ & $\begin{array}{l}\text { tidak dapat } \\
\text { disimpulkan }\end{array}$ & $\begin{array}{l}\text { tidak dapat } \\
\text { disimpulkan }\end{array}$ \\
\hline $\begin{array}{l}\text { Kontribusi pendanaan unit-unit } \\
\text { usaha terhadap pengembangan } \\
\text { mutu akademik }\end{array}$ & $\begin{array}{l}\text { tidak dapat } \\
\text { disimpulkan }\end{array}$ & $\begin{array}{l}\text { tidak dapat } \\
\text { disimpulkan }\end{array}$ & $\begin{array}{l}\text { tidak dapat } \\
\text { disimpulkan }\end{array}$ \\
\hline $\begin{array}{l}\text { Pendapatan organisasi publik dan } \\
\text { organisasi non profit luar negeri } \\
\text { terhadap total anggaran STAIN }\end{array}$ & $\begin{array}{l}\text { tidak dapat } \\
\text { disimpulkan }\end{array}$ & $\begin{array}{l}\text { tidak dapat } \\
\text { disimpulkan }\end{array}$ & $\begin{array}{l}\text { tidak dapat } \\
\text { disimpulkan }\end{array}$ \\
\hline
\end{tabular}




\begin{tabular}{|c|c|c|c|}
\hline $\begin{array}{l}\text { Pendapatan organisasi publik dan } \\
\text { organisasi non profit luar negeri } \\
\text { terhadap total anggaran STAIN }\end{array}$ & $\begin{array}{l}\text { tidak dapat } \\
\text { disimpulkan }\end{array}$ & $\begin{array}{l}\text { tidak dapat } \\
\text { disimpulkan }\end{array}$ & $\begin{array}{l}\text { tidak dapat } \\
\text { disimpulkan }\end{array}$ \\
\hline $\begin{array}{l}\text { Pendapatan dari pemerintah (da- } \\
\text { lam jutaan rupiah) }\end{array}$ & kurang baik & kurang baik & kurang baik \\
\hline $\begin{array}{l}\text { Pendapatan dari mitra dalam } \\
\text { negeri terhadap total anggaran } \\
\text { STAIN }\end{array}$ & $\begin{array}{l}\text { tidak dapat } \\
\text { disimpulkan }\end{array}$ & $\begin{array}{l}\text { tidak dapat } \\
\text { disimpulkan }\end{array}$ & $\begin{array}{l}\text { tidak dapat } \\
\text { disimpulkan }\end{array}$ \\
\hline $\begin{array}{l}\text { Pendapatan dari mahasiswa } \\
\text { STAIN (dalam jutaan rupiah) }\end{array}$ & cukup baik & cukup baik & cukup baik \\
\hline $\begin{array}{l}\text { Unit cost pendidikan per maha- } \\
\text { siswa per tahun (dalam jutaan } \\
\text { rupiah) }\end{array}$ & baik & baik & baik \\
\hline $\begin{array}{l}\text { Anggaran pemeliharaan sarana } \\
\text { teknologi informasi dalam rangka } \\
\text { mengefektifkan sistem informasi } \\
\text { akademik }\end{array}$ & cukup baik & cukup baik & cukup baik \\
\hline $\begin{array}{l}\text { Jumlah karyawan yang mengikuti } \\
\text { pelatihan bidang pemeriksaan } \\
\text { laporan keuangan }\end{array}$ & kurang baik & kurang baik & kurang baik \\
\hline $\begin{array}{l}\text { Jumlah sarana teknologi } \\
\text { informasi yang dapat digunakan } \\
\text { dengan baik kurang baik tahun } \\
\text { terakhir }\end{array}$ & kurang baik & kurang baik & kurang baik \\
\hline $\begin{array}{l}\text { Total sarana teknologi informasi } \\
\text { yang tersedia kurang baik tahun } \\
\text { terakhir }\end{array}$ & kurang baik & kurang baik & kurang baik \\
\hline
\end{tabular}

Sumber: Data penelitian diolah.

Pada tabel 3 menunjukkan terjadi persamaan implementasi balanced scorecard dalam perspektif manajemen administrasi dan keuangan (administration and finance) pada STAIN di Jawa Tengah dalam upaya meningkatkan mutu pendidikan, oleh karena itu ada beberapa kebijakan yang perlu mendapat perhatian dari STAIN dalam meningkatkan kinerjanya antara lain:

\begin{tabular}{|c|l|rl|}
\hline No. & \multicolumn{1}{|c|}{ STAIN } & \multicolumn{1}{c|}{ Kebijakan } \\
\hline 1. & Kudus, & 1. & Meningkatkan anggaran untuk Kualitas sistem infor- \\
& $\begin{array}{l}\text { Pekalongan dan } \\
\text { Parwokerto }\end{array}$ & 2. & Meningkatkan nilai tingkat kinerja pelayanan \\
& Purwan (dalam jutaan rupiah) \\
\hline
\end{tabular}




\begin{tabular}{|l|l|}
\hline 3. Meningkatkan Economic value-added dari Unit Usaha \\
4. Meningkatkan kualitas SDM yang mengikuti pelatihan \\
bidang pemeriksaan laporan keuangan \\
5. Meningkatkan Nilai kesehatan finansial lembaga \\
6. Meningkatkan Kontribusi pendanaan unit-unit usaha \\
terhadap pengembangan mutu akademik \\
7. Meningkatkan pendapatan organisasi publik dan orga- \\
nisasi non profit luar negeri terhadap total anggaran \\
STAIN \\
8. Meningkatkan pendapatan dari pemerintah \\
9. Meningkatkan pendapatan dari mitra dalam negeri \\
terhadap total anggaran STAIN \\
$\begin{array}{l}\text { 10. Menurunkan pendapatan dari mahasiswa STAIN } \\
\text { 11. Meningkatkan anggaran pemeliharaan sarana tekno- } \\
\text { logi informasi dalam rangka mengefektifkan sistem } \\
\text { informasi akademik } \\
\text { 12. Meningkatkan jumlah karyawan yang mengikuti } \\
\text { pelatihan bidang pemeriksaan laporan keuangan } \\
\text { 13. Meningkatkan jumlah sarana teknologi informasi } \\
\text { 14. Meningkatkan seluruh sarana teknologi informasi } \\
\text { yang tersedia }\end{array}$ \\
\hline
\end{tabular}

3. Implementasi balanced scorecard dalam perspektif proses pendidikan dan pengembangan (teaching and learning) dapat dijelaskan pada tabel 4.

Tabel 4.

Balanced Scorecard dalam Perspektif Proses Pendidikan dan Pengembangan (Teaching and Learning) pada STAIN di Jawa Tengah

\begin{tabular}{|l|l|l|l|}
\hline \multirow{2}{*}{$\begin{array}{c}\text { Perspektif Proses Pendidikan dan } \\
\text { Pengembangan (Teaching and } \\
\text { Learning) }\end{array}$} & \multicolumn{3}{|c|}{ STAIN } \\
\cline { 2 - 4 } & Kudus & Pekalongan & Purwokerto \\
\hline $\begin{array}{l}\text { Relevansi kurikulum sesuai dengan per- } \\
\text { kembangan masyarakat }\end{array}$ & baik & baik & baik \\
\hline Jumlahkoleksiyang tersedia di perpustakaan & baik & baik & baik \\
\hline $\begin{array}{l}\text { Jumlah dosen yang mengajar sesuai de- } \\
\text { ngan keahlian atau latar belakang pen- } \\
\text { didikannya }\end{array}$ & $\begin{array}{l}\text { tidak } \\
\text { baik }\end{array}$ & baik & baik \\
\hline
\end{tabular}




\begin{tabular}{|c|c|c|c|}
\hline Jumlah dosen berpendidikan S2 dan S3 & $\begin{array}{l}\text { tidak } \\
\text { baik }\end{array}$ & kurang baik & cukup baik \\
\hline Rasio komposisi dosen per mahasiswa & $\begin{array}{l}\text { tidak } \\
\text { baik }\end{array}$ & cukup baik & baik \\
\hline Rasio jumlah pegawai per mahasiswa & $\begin{array}{l}\text { kurang } \\
\text { baik }\end{array}$ & baik & kurang baik \\
\hline $\begin{array}{l}\text { Jumlah dosen yang mengikuti studi } \\
\text { lanjut (Stidak baik dan Skurang baik) }\end{array}$ & baik & cukup baik & cukup baik \\
\hline $\begin{array}{l}\text { Prosentase pegawai/staf struktural yang } \\
\text { dapat menduduki jabatan dan/ melaksana- } \\
\text { kan tugas sesuai dengan keahliannya. }\end{array}$ & baik & $\begin{array}{l}\text { tidak dapat } \\
\text { disimpulkan }\end{array}$ & $\begin{array}{l}\text { tidak dapat } \\
\text { disimpulkan }\end{array}$ \\
\hline $\begin{array}{l}\text { Prosentase pegawai yang mendapatkan } \\
\text { predikat baik }\end{array}$ & baik & $\begin{array}{l}\text { tidak dapat } \\
\text { disimpulkan }\end{array}$ & $\begin{array}{l}\text { tidak dapat } \\
\text { disimpulkan }\end{array}$ \\
\hline $\begin{array}{l}\text { Prosentase dosen yang mendapatkan } \\
\text { predikat baik }\end{array}$ & baik & $\begin{array}{l}\text { tidak dapat } \\
\text { disimpulkan }\end{array}$ & $\begin{array}{l}\text { tidak dapat } \\
\text { disimpulkan }\end{array}$ \\
\hline $\begin{array}{l}\text { Prosentase pejabat struktural yang ber- } \\
\text { kinerja baik }\end{array}$ & baik & $\begin{array}{l}\text { tidak dapat } \\
\text { disimpulkan }\end{array}$ & $\begin{array}{l}\text { tidak dapat } \\
\text { disimpulkan }\end{array}$ \\
\hline Prosentase pegawai yang berkinerja baik & baik & $\begin{array}{l}\text { tidak dapat } \\
\text { disimpulkan }\end{array}$ & $\begin{array}{l}\text { tidak dapat } \\
\text { disimpulkan }\end{array}$ \\
\hline $\begin{array}{l}\text { Rata-rata indeks kepuasan dosen dan } \\
\text { pegawai atas pelayanan kepegawaian, } \\
\text { keuangan, IT dan umum }\end{array}$ & baik & $\begin{array}{l}\text { tidak dapat } \\
\text { disimpulkan }\end{array}$ & $\begin{array}{l}\text { tidak dapat } \\
\text { disimpulkan }\end{array}$ \\
\hline
\end{tabular}

Sumber: Data penelitian diolah.

Pada tabel 4 menunjukkan terjadi perbedaan implementasi balanced scorecard dalam perspektif proses pendidikan dan pengembangan (teaching and learning) pada STAIN di Jawa Tengah dalam upaya meningkatkan mutu pendidikan, oleh karena itu ada beberapa kebijakan yang perlu mendapat perhatian dari STAIN dalam meninkatkan kinerjanya antara lain:

\begin{tabular}{|c|l|ll|}
\hline No. & STAIN & \multicolumn{1}{c|}{ Kebijakan } \\
\hline 1 & Kudus & 1. & Meningkatkan jumlah dosen yang mengajar sesuai dengan \\
& & keahlian atau latar belakang pendidikannya & 2. \\
& & Meningkatkan Jumlah dosen berpendidikan S3 \\
\hline
\end{tabular}




\begin{tabular}{|c|c|c|}
\hline & & $\begin{array}{l}\text { 3. Meningkatkan Rasio komposisi dosen per mahasiswa } \\
\text { menuju rasio ideal } \\
\text { 4. Meningkatkan rasio jumlah pegawai per mahasiswa yang } \\
\text { ideal } \\
\text { 5. Meningkatkan kepuasan dosen dan pegawai atas pelayanan } \\
\text { kepegawaian, keuangan, IT dan umum }\end{array}$ \\
\hline 2 & Pekalongan & $\begin{array}{l}\text { 1. Meningkatkan jumlah dosen berpendidikan S3. } \\
\text { 2. Meningkatkan rasio komposisi dosen per mahasiswa menuju } \\
\text { ideal } \\
\text { 3. Meningkatkan jumlah dosen yang mengikuti studi lanjut (S2 } \\
\text { dan S3) } \\
\text { 4. Meningkatkan Jumlah pegawai/staf struktural yang dapat } \\
\text { menduduki jabatan dan/ melaksanakan tugas sesuai dengan } \\
\text { keahliannya. } \\
\text { 5. Meningkatkan jumlah pegawai yang mendapatkan predikat } \\
\text { baik } \\
\text { 6. Meningkatkan jumlah dosen yang mendapatkan predikat } \\
\text { baik } \\
\text { 7. Meningkatkan Jumlah pejabat struktural yang berkinerja } \\
\text { baik } \\
\text { 8. Meningkatkan Prosentase pegawai yang berkinerja baik } \\
\text { 9. Meningkatkan Rata-rata indeks kepuasan dosen dan } \\
\text { pegawai atas pelayanan kepegawaian, keuangan, IT dan } \\
\text { umum }\end{array}$ \\
\hline 3 & Purwokerto & $\begin{array}{l}\text { 1. Meningkatkan rasio komposisi dosen per mahasiswa menuju } \\
\text { ideal } \\
\text { 2. Meningkatkan jumlah dosen yang mengikuti studi lanjut (S2 } \\
\text { dan S3) } \\
\text { 3. Meningkatkan jumlah pegawai/staf struktural yang dapat } \\
\text { menduduki jabatan dan/ melaksanakan tugas sesuai dengan } \\
\text { keahliannya. } \\
\text { 4. Meningkatkan jumlah pegawai yang mendapatkan predikat } \\
\text { baik } \\
\text { 5. Meningkatkan jumlah dosen yang mendapatkan predikat baik } \\
\text { 6. Meningkatkan Jumlah pejabat struktural yang berkinerja } \\
\text { 7. Menik } \\
\text { 8. Meningkatkan kepuasan dosen dan pegawai atas pelayanan } \\
\text { kepegawaian, keuangan, IT dan umum. }\end{array}$ \\
\hline
\end{tabular}


4. Implementasi balanced scorecard dalam perspektif dalam perspektif etos kerja dan budaya (ethos and culture) dapat dijelaskan pada tabel 5 .

Tabel 5.

Balanced Scorecard dalam Perspektif Etos Kerja dan Budaya (Ethos and Culture) pada STAIN di Jawa Tengah

\begin{tabular}{|c|c|c|c|}
\hline \multirow{2}{*}{$\begin{array}{l}\text { Perspektif Etos Kerja Dan } \\
\text { Budaya (Ethos And Culture) }\end{array}$} & \multicolumn{3}{|c|}{ STAIN } \\
\hline & Kudus & Pekalongan & Purwokerto \\
\hline $\begin{array}{l}\text { Rata-rata indeks kepuasan maha- } \\
\text { siswa terhadap pelayanan aka- } \\
\text { demik }\end{array}$ & cukup baik & kurang baik & baik \\
\hline $\begin{array}{l}\text { Rata-rata indeks kepuasan maha- } \\
\text { siswa terhadap pelayanan non } \\
\text { akademik }\end{array}$ & cukup baik & kurang baik & baik \\
\hline $\begin{array}{l}\text { Rata-rata indeks kepuasan alumni } \\
\text { dan/ atau masyarakat terhadap pe- } \\
\text { layanan non akademik }\end{array}$ & cukup baik & kurang baik & baik \\
\hline $\begin{array}{l}\text { Prosentase daya serap kurikulum } \\
\text { yang sesuai dengan perkembangan } \\
\text { kebutuhan akademik. }\end{array}$ & cukup baik & baik & cukup baik \\
\hline $\begin{array}{l}\text { Prosentase sarjana yang lulus de- } \\
\text { ngan rata-rata masa pendidikan } \leq \\
\text { baiktahun }\end{array}$ & cukup baik & $\begin{array}{l}\text { tidak dapat } \\
\text { disimpulkan }\end{array}$ & $\begin{array}{l}\text { tidak dapat } \\
\text { disimpulkan }\end{array}$ \\
\hline $\begin{array}{l}\text { Prosentase sarjana yang lulus de- } \\
\text { ngan } I P K \geq 3,00\end{array}$ & cukup baik & $\begin{array}{l}\text { tidak dapat } \\
\text { disimpulkan }\end{array}$ & $\begin{array}{l}\text { tidak dapat } \\
\text { disimpulkan }\end{array}$ \\
\hline $\begin{array}{l}\text { Mahasiswa program pascasarjana } \\
\text { yang lulus pendidikan } \leq 3 \text { tahun }\end{array}$ & $\begin{array}{l}\text { tidak dapat } \\
\text { disimpulkan }\end{array}$ & $\begin{array}{l}\text { tidak dapat } \\
\text { disimpulkan }\end{array}$ & $\begin{array}{l}\text { tidak dapat } \\
\text { disimpulkan }\end{array}$ \\
\hline $\begin{array}{l}\text { Prosentase Pascasarjana yang lulus } \\
\text { dengan } \mathrm{IPK} \geq 3,00\end{array}$ & $\begin{array}{l}\text { tidak dapat } \\
\text { disimpulkan }\end{array}$ & $\begin{array}{l}\text { tidak dapat } \\
\text { disimpulkan }\end{array}$ & $\begin{array}{l}\text { tidak dapat } \\
\text { disimpulkan }\end{array}$ \\
\hline $\begin{array}{l}\text { Prosentase Fakultas yang dapat } \\
\text { menerapkan metode belajar sesuai } \\
\text { dengan manual penjaminan mutu } \\
\text { pendidikan. }\end{array}$ & baik & baik & baik \\
\hline $\begin{array}{l}\text { Peningkatan pengetahuan pegawai } \\
\text { terhadap penggunaan dan akses } \\
\text { teknologi informasi }\end{array}$ & cukup baik & $\begin{array}{l}\text { tidak dapat } \\
\text { disimpulkan }\end{array}$ & $\begin{array}{l}\text { tidak dapat } \\
\text { disimpulkan }\end{array}$ \\
\hline $\begin{array}{l}\text { Peningkatan ketersedia-an dan } \\
\text { penggunaan sarana teknologi dan } \\
\text { informasi bagi pegawai }\end{array}$ & cukup baik & $\begin{array}{l}\text { tidak dapat } \\
\text { disimpulkan }\end{array}$ & $\begin{array}{l}\text { tidak dapat } \\
\text { disimpulkan }\end{array}$ \\
\hline
\end{tabular}

Sumber: Data penelitian diolah 
Pada tabel 5 menunjukkan terjadi perbedaan implementasi balanced scorecard dalam perspektif proses pendidikan dan pengembangan (teaching and learning) pada STAIN di Jawa Tengah dalam upaya meningkatkan mutu pendidikan, oleh karena itu ada beberapa kebijakan yang perlu mendapat perhatian dari STAIN dalam meningkatkan kinerjanya antara lain:

\begin{tabular}{|c|l|ll|}
\hline No. & \multicolumn{1}{|c|}{ STAIN } & \multicolumn{1}{c|}{ Kebijakan } \\
\hline 1 & Kudus & $\begin{array}{l}\text { 1. } \\
\text { Meningkatkan kepuasan mahasiswa terhadap pelayan- } \\
\text { an akademik }\end{array}$ & $\begin{array}{l}\text { 2. } \\
\text { Meningkatkan daya serap kurikulum yang sesuai de- } \\
\text { ngan perkembangan kebutuhan akademik. }\end{array}$ \\
& 3eningatkan kepuasan mahasiswa terhadap pelayan- \\
an non akademik
\end{tabular}

5. Implementasi balanced scorecard dalam perspektif Good Governance dapat dijelaskan pada tabel 6 . 
Tabel 6.

Balanced Scorecard dalam Perspektif Good Governance pada STAIN di Jawa Tengah

\begin{tabular}{|l|l|l|l|}
\hline \multirow{2}{*}{ Perspektif Good Governance } & \multicolumn{2}{c|}{ STAIN } \\
\cline { 2 - 4 } & Kudus & Pekalongan & Purwokerto \\
\hline Akuntabilitas & kurang baik & tidak baik & cukup baik \\
\hline Transparansi & kurang baik & tidak baik & kurang baik \\
\hline Efisiensi & kurang baik & kurang baik & kurang baik \\
\hline Aturan Hukum & kurang baik & kurang baik & cukup baik \\
\hline Perlakuan yang adil (fairness) & kurang baik & tidak baik & cukup baik \\
\hline
\end{tabular}

Sumber: Data penelitian diolah

Pada tabel 6 menunjukkan terjadi perbedaan implementasi balanced scorecard dalam perspektif good governance pada STAIN di Jawa Tengah dalam upaya meningkatkan mutu pendidikan, oleh karena itu ada beberapa kebijakan yang perlu mendapat perhatian dari STAIN dalam meninkatkan kinerjanya antara lain:

\begin{tabular}{|c|c|c|}
\hline No. & STAIN & Kebijakan \\
\hline \multirow[t]{2}{*}{1} & Kudus & $\begin{array}{l}\text { 1. Memberi kesempatan yang sama kepada semua pihak } \\
\text { (dosen, karyawan, mahasiswa) }\end{array}$ \\
\hline & & $\begin{array}{l}\text { 2. Memberi kebebasan untuk turut berpartisipasi kepada } \\
\text { semua pihak (karyawan, dosen dan mahasiswa) } \\
\text { 3. Memberi kebebasan kepada semua pihak (dosen, } \\
\text { karyawan, mahasiswa) untuk mengeluarkan pendapat } \\
\text { dalam rangka meningkatkan pendidikan lembaga. } \\
\text { 4. Mementingkan kepentingan lembaga diatas golongan } \\
\text { 5. Meningkatkan kemudahan akses terhadap para pembuat } \\
\text { keputusan lembaga, } \\
\text { 6. Meningkatkan kejelasan informasi yang diberika lembaga, } \\
\text { 7. Meningkatkan transparansi atas proses dan informasi } \\
\text { layanan dapat langsung diterima oleh stakholder }\end{array}$ \\
\hline 2 & Pekalongan & $\begin{array}{l}\text { 1. Mmeningkatkan Pengelolaan lembaga atas pengelolaan } \\
\text { dan pengendalian sumberdaya yang dimiliki lembaga } \\
\text { 2. Meningkatkan pengelolaan dosen dan karyawan atas } \\
\text { pengelolaan dan pengendalian sumberdaya yang dimiliki } \\
\text { lembaga }\end{array}$ \\
\hline
\end{tabular}




\begin{tabular}{|c|c|c|}
\hline & & $\begin{array}{l}\text { 3. Meningkatkan pertanggungjawaban lembaga atas setiap } \\
\text { pelaksanaan kegiatan/program lembaga, } \\
\text { 4. Meningkatkan pertanggungjawaban dosen dan karyawan } \\
\text { atas setiap pelaksanaan kegiatan yang berhubungan } \\
\text { dengan layanan kemahasiswaan serta } \\
\text { 5. Meningkatkan ketersediaan media yang digunakan oleh } \\
\text { lembaga untuk mempertanggungjawabkan program } \\
\text { kegiatan secara periodik } \\
\text { 6. Memberi kesempatan yang sama kepada semua pihak } \\
\text { (dosen, karyawan, mahasiswa) } \\
\text { 7. Memberi kebebasan untuk turut berpartisipasi kepada } \\
\text { semua pihak (karyawan, dosen dan mahasiswa) } \\
\text { 8. Memberi kebebasan kepada semua pihak (dosen, } \\
\text { karyawan, mahasiswa) untuk mengeluarkan pendapat } \\
\text { dalam rangka meningkatkan pendidikan lembaga. } \\
\text { 9. Mementingan kepentingan lembaga di atas golongan }\end{array}$ \\
\hline 3 & Purwokerto & $\begin{array}{l}\text { 1. Meningkatkan kemudahan akses informasi yang dilaku- } \\
\text { kan dengan menyediakan beberapa media informasi dan } \\
\text { informasi itu online sehingga dapat di akses oleh stake- } \\
\text { holders. } \\
\text { 2. Meningkatkan kejelasan informasi yang diberikan lem- } \\
\text { baga, } \\
\text { 3. Meningkatkan transparansi atas proses dan informasi } \\
\text { layanan dapat langsung diterima oleh stakholder }\end{array}$ \\
\hline
\end{tabular}

\section{F. Kesimpulan}

Implementasi balanced scorecard pada STAIN memerlukan data dan dokumen yang akurat, hal ini untuk mengetahui perubahan-perubahan pada indikator kunci yang dapat dijadikan sebagai bukti dasar kegiatan organisasi. Namun realita dilapangan banyak sekali yang tidak terdokumentasi data dengan baik sehingga dari berbagai perspektif masih terdapat beberapa kelemahan-kelmahan. Jadi pada hakekatnya implementasi balanced scorecard pada STAIN dapat dilakukan berdasarkan kajian-kajian dari berbagai aspek, dan oleh peneliti scorecard pada empat pesrpektif dilakukan modifikasi menjadi 5 (lima) perseptif yang disesuai dengan karakteristik yang dimilki STAIN sebagai lembaga pendidikan tinggi Islam. Dalam penelitian ini, perspektif yang digunakan adalah perspektif pemangku kepentingan (stakeholders), manajemen administrasi dan keuangan (administration and finance), 
proses pendidikan dan pengembangan (teaching and learning), etos kerja dan budaya (ethos and culture) dan good governance.

Dalam upaya meningkatkan mutu pendidikan pada STAIN, dalam perspektif pemangku kepentingan peningkatan kerjasama, peningkatan lulusan yang dapat bekerja, peningkatan bea siswa bagi mahasiswa miskin dan berprestasi, rekuitman untuk mahasiswa berprestasi perlu dilakukan dalam rangka meningkatkan mutu pendidikan STAIN di Jawa tengah. Pada perspektif perspektif manajemen administrasi dan keuangan (administration and finance)peningkatan value added unit usaha, peningkatan kesehatan keuangan lembaga, peningkatan kontribusi dari unit uasaha kerjasama dalam dan luar negeri dalam memberi kontribusitotal pendapatan, menurunkan kontribusi dari mahasiswa serta peningkatan SDM dibidang administrasi keuangan. Semua ini dilakukan dalam rangka meningkatkan pendapatan atau anggaran dalam rangka optimalisasi unit usaha dan kerjasama, dalam rangka sustainebilitas dan kemandirian dalam pengelenggaraan pendidikan STAIN yang bermutu.

Dalam perspektif proses pendidikan dan pengembangan, peningkatan jumlah dosen yang mengajar sesuai dengan keahlian atau latar belakang pendidikannya, peningkatan dosen berpendidikan S3, peningkatan rasio komposisi dosen per mahasiswa menuju rasio ideal, peningkatan rasio jumlah pegawai per mahasiswa yang ideal, peningkatan dosen dan karyawan berpredikat baik dan peningkatan kepuasan dosen dan pegawai, hal ini dapat menciptakan proses belajar mengajar yang baik dalam rangka mendukung terciptanya mutu pendidikan di STAIN. Dalam perspektif etos kerja dan budaya (ethos and culture) melalui peningkatan kepuasan mahasiswa, alumni, dosen dan pegawai atas layanan akademik dan non akademik, Peningkatan pengetahuan pegawai terhadap penggunaan dan akses teknologi informasi serta peningkatan ketersediaan dan penggunaan sarana teknologi dan informasi bagi pegawai, hal ini dapat menciptakan iklim budaya dan motivasi kerja yang baik dalam rangka mendukung penciptaan mutu pendidikan di STAIN.

Dalam perpektif good governance melalui peningkatan indikatorindikator antara lain akuntabilitas, transparansi, efisien, aturan hukum serta keadilan, hal ini akan berdampak pada peningkatan kinerja tata kelola kelembagaan STAIN dalam upaya peningkatan mutu pendidikan.[w] 


\section{BIBLIOGRAFI}

Averson, Paul, "A Balanced Scorecard for City \& County Services," http:// www.balanced scorecard.org, diakses pada tanggal 25 Agustus 2011.

"Building a Government Balanced Scorecard: Phase 2 -Implementation and Automation," http://www.balanced scorecard.org, diakses pada tanggal 25 Agustus 2011.

"Balanced Scorecard as a Control System for Monitoring and Revising Corporate Strategy," http://www.ssrn.com, diakses pada tanggal 12 Februari 2011.

Gazperz, Vincent, Sistem Pengukuran Kinerja Terintegrasi Balanced Scorecard dengan Six Sigma untuk Organisasi Pemerintah, Jakarta, Gramedia Pustaka Utama, 2002.

Giri, Efraim Ferdinan, "Balanced Scorecard: Suatu Sistem Pengukuran Kinerja Strategik," Kajian Bisnis, No. 13, Edisi Januari-April 1998, h. 35-46.

Kaplan, R. and Norton, D., "Putting The Balanced Scorecard to Work," Harvard Business Review, September-October 1993, p. 134-142 "The Balanced Scorecard - Measures That Drive Performance," Harvard Business Review, January-February 1992,p. 71-79 "Using The Balanced Scorecard As A Strategic Management System," Harvard Business Review, January-February 1996a, p. 75-85

The Balanced Scorecard: Translating a Strategy into Action, Harvard Business School Press, Boston, 1996b.

Kaplan, Robert S and David P Norton, "Putting the Balanced Scorecard to Work," Harvard Business Review, 1993.

Balanced Scorecard: Menerapkan Strategi Menjadi Aksi, Erlangga: Jakarta, 1996.

Balanced Scorecard: Translating Strategy Into Action, Boston: Havard Business School Press, 1996.

Laela, Fatma, "Balanced Scorecard: Sebagai Alternatif Pengukuran Kinerja Manajemen." Jurnal Teknologi Bisnis, Vol. 2 No. 1, Tahun 1998.

Lasdi, Lodovicus. Agustus, "Balanced Scorecard sebagai Rerangka Pengukuran Kinerja Perusahaan Secara Komprehensif dalam Lingkungan Bisnis Global," Jurnal Widya Manajemen dan Akuntansi, Vol.2 No. 2, Tahun 2002, h. 150-169. 
Mahmudi, Manajemen Kinerja Sektor Publik, Yogyakarta: UPP STIM YKPN, 2007.

Malina, Mary, A. dan Selto, Frank, H., "Communicating and Controlling Strategy: an Emperical Study of the Effectiveness of the Balanced Scorecard," http://www.ssrn.com, diakses pada tanggal 8 Februari 2011.

Mulyadi dan Setyawan Jhony, Sistem Perencanaan dan Pengendalian manajemen: Sistem Pelipatgandaan Kinerja Keuangan Perusahaan, Salemba Empat: Jakarta, 2001.

Mowen, J.C, Customer Behavior, New Jersey: Prentice Hall Inc., 1995.

Mulyadi, "Strategic Management System dengan Pendekatan Balanced Scorecard" (Bagian Pertama dari Dua Tulisan), Usahawan, No 02, Tahun XXVIII, Februari, 1999, h. 39-46.

"Strategic Management System dengan Pendekatan Balanced Scorecard" (Bagian Akhir dari Dua Tulisan), Usahawan, No. 03, Tahun XXVIII, Maret, 1999, h. 36-41.

Sistem Perencanaan dan Pengendalian Manajemen, Yogyakarta: Aditya Media, 1999. Balanced Scorecard, Salemba Empat, Jakarta, 2001.

, Balanced Scorecard: Alat Manajemen Kontemporer untuk Pelipatgandaan Kinerja Keuangan Perusahaan, Salemba Empat: Jakarta, 2001.

Rohm, Howard, "Improve Public Sector results With A Balanced Scorecard: Nine Steps To Succcess," http://www.balancedscorecard.org, diakses pada tanggal 25 Agustus 2011.

Sumarni, Murti dan John Soeprihanto, Pengantar Bisnis, Yogyakarta: Liberty, 1998.

Yuwono, Sony, Petunjuk Praktis Penyusunan Balanced Scorecard: Menuju Organisasi Yang Berfokus Pada Strategi, Jakarta: Gramedia Pustaka Utama, 2002.

Zaeni, "Strategi Pengukuran Kinerja Sektor Publik dengan Kerangka Balanced Scorecard," MGS, Vol. 5 No. 32, Desember 2000, h. 13-38. 
